\title{
O SIGNIFICADO SOCIAL DOS TERMOS E EXPRESSÕES REFERENTES A EPIDEMIAS NO CEARÁ OITOCENTISTA
}

\author{
Francisco de Freitas LEITE* \\ Maria de Fátima ALMEIDA**
}

- RESUMO: Este artigo objetiva analisar o significado social dos termos e expressões referentes a epidemias de cólera e de varíola que acometeram milhares de pessoas no Ceará durante o século XIX, sobretudo a partir de um corpus constituído da novela de 1899, Violação, de Rodolfo Teófilo; e de textos jornalísticos do semanário O Araripe, impresso de 1855 a 1864 em Crato-Ceará. É um trabalho que se situa no âmbito da Linguística Histórica lato sensu, sendo utilizada como metodologia de análise essencialmente aquela da História Social da Linguagem, nos moldes dos trabalhos de Burke e Porter (1993, 1997) e Burke (2010). Também subjazem ao nosso trabalho analítico as propostas teóricas de Benveniste $(1995,1989)$, principalmente aquelas que abordam a relação que se estabelece entre língua e realidade ou entre léxico e cultura. Nossas conclusões, advindas das análises, apontam para a necessidade de entendermos a linguagem não como simulacro da realidade, mas como parte viva da realidade social, cultural e histórica do homem. A relação entre as palavras e as doenças pode ser marcada por concepções e preconceitos históricos e socioculturais e revelar as funções sociais que tem a linguagem.

- PALAVRAS-CHAVE: Linguística histórica. História social da Linguagem. Violação, de Rodolfo Teófilo. Semanário O Araripe. Enfermidades. Língua e realidade.

Cada geração, vivendo com os problemas do presente, interroga

o passado pensando em suas próprias questões. [...] Mas ao mesmo tempo que usamos o presente para formular perguntas, temos que deixar o passado dar suas próprias respostas.

Peter Burke (2009).

\footnotetext{
* URCA - Universidade Regional do Cariri. Departamento de Línguas e Literatura. Crato - CE - Brasil. 63105000 - freitas_leite@hotmail.com

** UFPB - Universidade Federal da Paraíba. Departamento de Letras Clássicas e Vernáculas - João Pessoa - PB Brasil. 58059-900 - falmed@uol.com.br
} 


\section{Considerações iniciais}

O temor que a população tem hoje da cólera, da varíola ou de outra doença qualquer que possa surgir de forma epidêmica não é exatamente como acontecia há 100 ou 150 anos. As condições de higiene e de profilaxia mudaram, os medicamentos e a medicina avançaram, as crenças místico-religiosas em relação às enfermidades também mudaram e isso se revela de variadas maneiras, inclusive linguisticamente. Apesar de não ser a mudança linguística o foco principal deste trabalho, podemos dizer que uma vista d'olhos sobre os termos e expressões referentes às doenças como surgem em textos do século XIX em comparação com a maneira como aparecem nos dias de hoje, tanto na literatura artística quanto na imprensa jornalística, revelam realidades distintas, quase como se se comparassem mundos distintos.

Para se ter uma ideia da extensão da mortandade que a cólera causou no Ceará no ano de 1862 e, consequentemente, para se vislumbrar o terror que essa doença produziu, consideremos as informações colhidas por Otacílio Colares a partir da obra Datas e fatos para a história do Ceará, do Barão de Studart, segundo o qual, no dia 5 de abril de 1862,

[...] manifesta-se na província, pela primeira vez, a epidemia de cóleramorbo, declarando-se o flagelo na cidade de Icó, por transmissão da Paraíba. [...] A epidemia, que tomou ali proporções aterradoras, propagou-se a muitos outros pontos da província. Na capital começou a reinar no dia 13 de maio. Em Baturité, Pacatuba, Maranguape, etc. fez horríveis estragos. Em fins de agosto do ano seguinte, achava-se extinta a epidemia em toda a província, elevando-se a mortandade a 11 mil vítimas. (STUDART, 1896 apud COLARES, 1979, p.Xvi).

Em algumas cidades, há relatos de que caía um número de 100 pessoas infectadas por dia e que, na cidade de Icó, 1/3 da população foi extinta pela epidemia. Não é para menos que, naquela época, uma epidemia dessa magnitude recebesse os epítetos de "anjo do extermínio"1 e "medonha peste" (TEÓFILO, 1979, p.236). Assim, essas expressões não podem ser analisadas apenas no nível da língua, pois seus significados só se mostram no contexto sociocultural e histórico de seus usos. Seus usos e significados sociais, aliás, só existiram em consequência das epidemias e do terror que elas causaram a uma população num contexto específico.

Neste trabalho, usaremos os modelos de análise qualitativa próprios da História Social da Linguagem, focando a atenção no significado social de termos

No original: "anjo do extreminio". O Araripe, n.10, p.2, 08 set. 1855. 
e de expressões referentes às epidemias de cólera e de varíola que assolaram o Ceará no século XIX.

Usaremos nas nossas pesquisas um corpus constituído de uma obra literária, a novela de 1899, Violação, de autoria do farmacêutico e escritor Rodolfo Teófilo, cujo enredo, com rasgos de memórias e recheado de termos científicos, passase em 1862 numa pequena vila do litoral do Ceará; e de textos jornalísticos do semanário O Araripe, impresso de 1855 a 1864 em Crato, cidade da região do Cariri, no sul do Ceará, sob a direção de um grupo de cidadãos ligados ao Partido Liberal, em que reiteradamente eram publicadas matérias que abordavam a varíola e a cólera, bem como os horrores que elas provocavam na população (O ARARIPE, 1855-1864).

Enfim, é preciso dizer que as transcrições dos trechos retirados da novela Violação, do semanário O Araripe e de outros textos do século XIX são ipsis litteris; portanto, nenhuma correção ou adaptação foi feita aos textos originais. Quando necessárias, notas de rodapé explicativas foram usadas nessas transcrições.

\section{Notas sobre as orientações de Linguística Histórica e de História Social da Linguagem deste trabalho}

Conforme o ponto de vista defendido por Rosa V. M. e Silva (2008, p.9): "A linguística histórica lato sensu trabalha com dados datados e localizados, como ocorre em qualquer trabalho de linguística baseado em corpora, que, necessariamente são datados e localizados." Sua ênfase não recai sobre a mudança, mas sim sobre as investigações sincrônicas, ressaltemos, de dados linguísticos com data e local delimitados.

Já a linguística histórica stricto sensu possui duas orientações: a linguística histórica sócio-histórica, que focaliza a mudança linguística considerando fatores intralinguísticos e também fatores sociais; e a linguística diacrônica associal, que focaliza a mudança apenas intralinguisticamente, ou seja, na língua vista como sistema. A filologia, por sua vez, é tida como a ciência responsável pela recuperação dos textos do passado, estes que são a base dos dados sobre os quais trabalhará a linguística histórica (SILVA, R., 2008).

O Gráfico 1 resume essa distinção: 


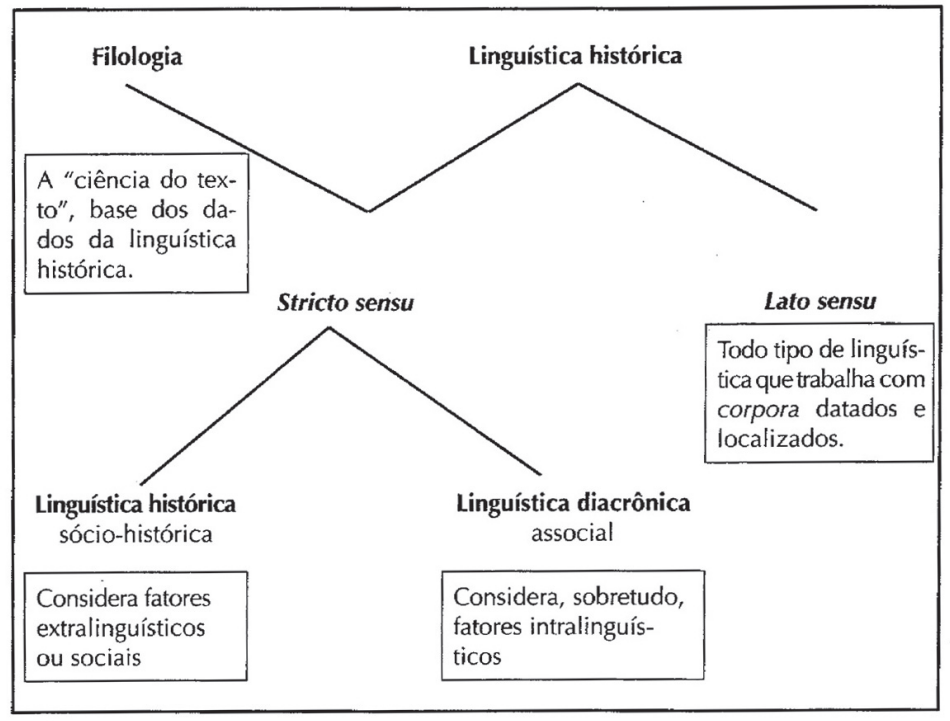

Fonte: (SILVA, R., 2008, p.10).

Este trabalho caracteriza-se, portanto, como sendo de natureza própria da linguística histórica lato sensu. Sua orientação metodológica e os modelos de análise, porém, são tipicamente os da História Social da Linguagem, cujas pesquisas:

[...] enfocam um estudo linguístico atrelado a um estudo histórico e sociocultural da comunidade que faz uso da(s) língua(s) ou dialeto(s) em questão.

Nesse sentido, sobressai-se o interesse pelas análises e interpretações do significado social dentro daquilo que é pesquisado numa dada comunidade. (LEITE, 2009, p.52).

E, no caso específico deste trabalho, nosso interesse recai sobre o significado social dos termos e expressões do universo das epidemias do Ceará oitocentista. Significado social que, podemos dizer,

[...] vai além da concepção de significado saussuriano (ou significado referencial): ela diz respeito, principalmente, aos valores atribuídos (tabus, preconceitos, etc.) histórica e socioculturalmente por um povo ou grupo de indivíduos a determinados vocábulos, ou expressões, ou a qualquer outro elemento gramatical em oposição a outro(s) num contexto determinado. (LEITE, 2009, p.52). 
Dessa forma, ressaltamos que as nossas análises não se restringem a uma especulação acerca das acepções dicionarizadas ou do significado entendido como idealização coletiva nos cérebros dos falantes de uma língua, ao modo da compreensão saussuriana da questão; antes, buscarão na concretude da realidade histórica e sociocultural sua existência. Dessa forma, o termo social se opõe a ideal. O significado social terá aqui, portanto, um valor que se refere ao grupo sociocultural e ao período histórico especificamente localizado e datado.

O interesse por se estudar a língua sem desvinculá-la da cultura nem da história vem crescendo a cada dia, para linguistas, historiadores e sociólogos. Isso pode ser percebido, por exemplo, pelo surgimento de novas áreas da linguística, tais como a linguística sócio-histórica e a sociolinguística histórica, como atesta Burke (2010).

Para Auroux (2009, p.64) “[...] entender uma língua não é apenas ter acesso a relações intralinguísticas, é mais: é ser capaz de relacionar esses signos linguísticos a uma experiência compartilhada de mundo." Dessa forma, um pesquisador que queira compreender uma língua em sua plenitude, não poderá prescindir do contexto sociocultural e histórico do qual ela é parte, ou incorrerá numa limitada visão de língua como estrutura autossuficiente.

Fazer pesquisa em linguística, que se interessa em analisar um fenômeno que é heteróclito e multifacetado, a despeito das concepções de Saussure, pressupõe entender que língua e linguagem estão entrelaçadas com cultura, sociedade, história e toda sorte de fenômenos intra e extralinguísticos que existem não somente na mente, mas também no entorno da realidade sociocultural e histórica dos indivíduos.

Sabemos que não é tarefa fácil, essa a que nos propomos, a de investigar as delicadas e sutis nuanças que constituem o significado social dos termos e expressões usados por indivíduos reais, o qual nem sempre corresponde àquele significado linguístico próprio das concepções de filiação saussuriana.

Nesse sentido, mas referindo-se especificamente à natureza do signo linguístico, é que Benveniste diz que o linguista costuma tratar o problema metafísico da relação entre o espírito e o mundo usando como artifício o viés da arbitrariedade, como se isso fosse uma

[...] forma de defender-se contra essa questão e também contra a solução que o falante lhe dá instintivamente. Para o falante há, entre a língua e a realidade, adequação completa: o signo encobre e comanda a realidade; ele é essa realidade (nomen omen, tabus de palavra, poder mágico do verbo, etc.). (BENVENISTE, 1995, p.57). 
Essa concepção de que o signo é a realidade, a propósito, é muito bem apresentada e analisada num ensaio de Roy Porter intitulado Expressando sua enfermidade: a linguagem da doença na Inglaterra georgiana, em que ele se dedica a perscrutar a ideia popularizada de que um nome é um agouro, ou seja, de que a palavra câncer, por exemplo, nem deve ser pronunciada, por causa do mal que ela pode trazer (PORTER, 1993).

A relação signo-mundo, muito comum na concretude da vida dos indivíduos, será um dos principais focos de investigação desta pesquisa, uma vez que nos posicionaremos: "[...] na condição de um linguista trabalhando em Antropologia.", usando as palavras de Hymes (1993, p.431), no posfácio que escreveu para o livro de ensaios Linguagem, indivíduo e sociedade.

\section{Sobre os textos que compõem o corpus das análises}

As obras literárias e os jornais (bem como os livros de história, as cantorias populares, etc.) registraram, cada um à maneira própria de seu gênero, as doenças no Ceará oitocentista, entretanto justificamos a opção por analisar gêneros de naturezas distintas para destacar que significados sociais de uso coloquial estavam tão arraigados no cotidiano das gentes de modo que foram incorporados também à literatura da época, sobretudo aquela de apelo realista.

De forma auxiliar, utilizaremos livros de história e dicionários antigos para contextualizar alguns fatos ou acepções de termos do passado, toda vez que considerarmos pertinentes recorrermos a estas fontes como forma de aclararmos o significado social que tinham as palavras ou as expressões analisadas.

Mas os textos principais, que correspondem ao corpus deste nosso trabalho, são a novela Violação, de autoria do escritor Rodolfo Teófilo, publicada em 1899, e um conjunto de edições do semanário O Araripe, em especial aquelas seções dos anos de 1855 a 1864 que abordam a temática das epidemias que assolavam o Ceará oitocentista.

Traçaremos a seguir uma síntese desses dois textos, a fim de que possamos situá-los no contexto social, histórico e cultural em que foram produzidos, de modo a justificar a sua utilização como registros válidos para as análises linguísticas e também socioculturais e históricas que iremos realizar.

\section{Violação, de Rodolfo Teófilo}

Rodolfo Teófilo nasceu em Salvador, em 6 de maio de 1853, e faleceu em Fortaleza, em 2 de julho de 1932. Participou de movimentos literários do Ceará, 
sendo, inclusive, membro da Padaria Espiritual, com o nome de "padeiro" Marcos Serrano. ${ }^{2}$ Foi farmacêutico, escritor e historiador. Escreveu, entre outros trabalhos, os romances: A Fome (de 1890), Os Brilhantes (de 1895), Maria Rita (de 1897) e O Paroara (de 1899); escreveu também o livro de informação histórico-científica Secas do Ceará: segunda metade do século XIX (de 1901) e o compêndio testemunhal de batalha contra a epidemia de varíola que ocorreu em Fortaleza Varíola e Vacinação (de 1905-1910).

Tendo vivido na infância os horrores causados pela epidemia de cólera em Maranguape, na época pequena vila do litoral do Ceará, onde seu pai era médico, publicou, em 1899, a novela Violação, que revela cientificismo, positivismo, determinismo, realismo, regionalismo, impressão e memórias, tudo misturado sob a égide do naturalismo literário do final do século XIX.

Otacílio Colares, na introdução crítica do livro que traz o romance A Fome e a novela Violação, especificamente sobre esta última, diz:

Uma estória, ou melhor, um episódio dramático, que tem sua origem, evolução e desfecho macabro à conta da bestialidade gerada em cérebros elementares, no delírio da febre e da lubricidade sem freios, tudo como consequência do advento de uma peste de cólera-morbo.

$\mathrm{Na}$ verdade, Violação é fruto, quanto ao enredo e seu final dantesco, de uma forte e ousada imaginação criadora, cevado no húmus de lembranças infantis do autor. (COLARES, 1979, p.xvi).

Não se trata, portanto, Violação de uma pura obra de ficção. Na verdade, ela traz, em seu bojo, traços de reminiscência e de memórias do autor, além de testemunhar linguística e historicamente aspectos socioculturais do Ceará oitocentista, especialmente no tocante à epidemia de cólera que ele vivenciou na infância.

Novela de poucas personagens, Violação traz como uma das personagens mais marcantes a própria peste de cólera e em torno dela uma série de termos e expressões, tais como peste, micróbios, cadáver, moribundos, febre, fezes, cemitério dos coléricos, castigo do céu, que configuram uma ambientação macabra, infecciosa, lúgubre, aterradora e dantesca, que se assemelha a um transe ou delírio, como se nota no epílogo, em que um cadáver de uma jovem, vítima de cólera fulminante, é violado sexualmente no cemitério, entre pilhas de mortos, por dois criminosos que pagavam pena como carregadores de defuntos, enquanto

\footnotetext{
A Padaria Espiritual foi uma agremiação literária e artística que existiu em Fortaleza entre os anos de 1892 e 1898. Seus componentes, que obrigatoriamente deveriam adotar cognomes, eram denominados padeiros, devido à finalidade da agremiação de fornecer pão de espírito aos seus sócios em particular e também aos povos em geral - entendido este pão de espírito como uma literatura de feições nacionalista e regional, além de bem-humorados princípios de conduta, tais como o de não recitar versos ao piano - e também por conta do jornal O Pão, que eles editavam.
} 
o noivo da jovem assiste a tudo desesperado, mas impossibilitado de falar e de se mover pelo estado de quase morte ou de letargia causado pela doença que o consumia.

\section{O Araripe}

O semanário O Araripe, de Crato, cidade do Cariri, região sul cearense, foi o primeiro jornal do interior do Ceará. Seu proprietário e também redator era o historiador e jornalista João Brígido dos Santos, que, juntamente com um grupo de comerciantes e profissionais liberais ligados ao Partido Liberal, fez circular este semanário entre os anos de 1855 e 1864.

Durante estes mais de nove anos de sua existência, esse jornal, como atesta Alves $(2010$, p.8), "[...] apresentou em seus artigos a necessidade de civilizar a região caririense, apresentando entre seus projetos de civilização a criação da 'Província dos Cariris Novos', cuja capital seria o Crato, por ser esta a cidade mais desenvolvida do Cariri."

Mas, mesmo com este propalado desenvolvimento do Crato, a cidade estava despreparada, com suas precárias condições sanitárias, como atesta Figueiredo Filho (2010), para combater uma epidemia que se aproximava ceifando vidas por onde passava.

Sobre o porquê do temor da cólera na cidade de Crato e da presença de várias matérias sobre essa doença no semanário O Araripe, Alexandre (2010, p.3) esclarece bem:

Por essa época o cólera percorria o território do Brasil, deixando um rastro de morte por onde passava. O medo de que o surto atingisse aquela cidade fez com que, desde 1855, O Araripe passasse a publicar, de forma enfática, uma série de textos sobre o tema. Assim, o jornal divulgou o percurso da peste pelas províncias brasileiras, reivindicou ou criticou a ação das autoridades públicas, expôs conselhos médicos para combater os sintomas característicos da doença, ensinou remédios caseiros e orações consideradas poderosas para debelar a moléstia, entre outros textos.

Dessa forma, O Araripe, em suas quatro páginas costumeiras (salvo quando apareciam suplementos que acresciam mais duas, três ou quatro páginas), concomitantemente à sua tarefa jornalística, terminava por fazer as vezes de outras formas de combate à cólera:

Os responsáveis pelo jornal o compreendiam como o espaço apropriado para ditar os melhores meios de combater a doença, diante da 
constatação que aparentavam ter da aproximação geográfica da mesma, da falta de médicos no Cariri cearense e da distância da região em relação à capital provincial, o que inviabilizava o socorro imediato em caso de contaminação. (ALEXANDRE, 2010, p.13).

Termos e expressões tais como "Cholera morbus", ${ }^{3}$ de propensão erudito-

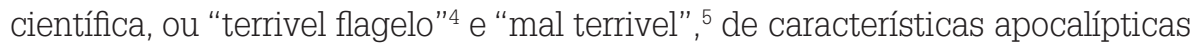
e religiosas, eram recorrentes em suas matérias sobre a cólera e sobre a varíola, o que pede um estudo linguístico, mas que também considere a história, o social e o cultural, no que se refere à maneira como a linguagem se manifesta no cotidiano dos homens como parte de sua realidade mais viva e não apenas como um modo de representá-la.

\section{Análises do significado social dos termos e expressões referentes às epidemias no Ceará do século XIX}

A linguagem está sempre necessariamente permeada de elementos de uma época, de uma sociedade e de uma cultura. Sua relação com a história é de interdependência. Isso não é nenhuma novidade, mas nosso objetivo não é só apresentar esta constatação, é estudar uma situação concreta em que isso se revela materialmente. Para tanto, focaremos a atenção das análises nas questões linguísticas considerando estas sempre inter-relacionadas com o seu contexto sociocultural e histórico.

À guisa de uma introdução de um aspecto linguístico e histórico da palavra cólera, que neste trabalho aparecerá várias vezes, ora em transcrições de textos antigos, ora como palavra de uso contemporâneo, apresentamos umas breves anotações sobre a questão do gênero gramatical dessa palavra.

No século XIX, era masculino o substantivo cholera (bem como sua variante: cholera-morbus) na acepção de moléstia ou doença, como se lê no Diccionario de medicina popular e das sciencias accessorias, de Chernoviz (1890, p.578): "0 cholera distingue-se em esporadico e epidemico", bem como em vários trechos aqui transcritos da novela Violação e do semanário O Araripe; mas era feminino o substantivo cólera (bem como sua variante: colera) com outras acepções, tais como ira, como registra o Diccionario da Lingua Brasileira, de Pinto (1832): "Colera s.f. Hum dos humores do corpo humano. Fig. Ira.", e o Diccionario da lingua portugueza, de Antonio de Morais Silva (1813, p.411): "Cólera, s.f. Um dos humores do corpo humano. § Ira, agastamento."

\footnotetext{
$3 \quad$ O Araripe, n.17, p.3, 27 out. 1855.

4 O Araripe, n.20, p.1, 17 nov. 1855.

5 O Araripe, n.1, p.3, 07 jul. 1855.
} 
Na atualidade, porém, o substantivo cólera aparece registrado nos dicionários apenas como sendo de gênero feminino, em quaisquer acepções, seja de doença ou de ira, como vemos, por exemplo, no dicionário Aurélio eletrônico:

\section{Cólera}

[Do gr. choléra, pelo lat. cholera, 'doença biliosa', 'ira'.]

Substantivo feminino.

1.Impulso violento contra o que nos ofende, fere ou indigna; ira, raiva, fúria, furor, zanga.

\section{A ferocidade dos animais: \\ a cólera do tigre. \\ 3.Fig. Ímpeto, agitação: \\ a cólera das ondas.}

4.Patol. Doença infecciosa aguda, contagiosa, que pode manifestar-se sob forma epidêmica, caracterizada, em sua apresentação clássica, por diarréia abundante, prostração e cãibras; cólera-morbo, mordexim. (FERREIRA, 2012).

Podemos conjeturar que essa diferença de gêneros para o substantivo cólera, que existia no século XIX (o cholera e a colera), fosse uma das formas (além da distinção gráfica) que os usuários da língua portuguesa tinham para melhor distinguir o nome dado para a doença do nome dado para a ira, como permitem supor os verbetes pesquisados em dicionários da época e também os textos analisados. Nossos objetivos nas investigações, porém, vão além de simplesmente anotar essa mudança de gênero do substantivo cólera.

Se lermos textos do passado com nossa compreensão restrita ao presente, perdem-se muitos detalhes de significado que tinham esses textos, inclusive significados dos termos e das expressões de então. Isso não é só porque o gênero gramatical das palavras pode mudar, como anotamos, nem só porque mudou a grafia de algumas palavras, tais como cholera, flagello, amiaça e molestia, grafadas hoje respectivamente: cólera, flagelo, ameaça e moléstia; nem só porque alguns termos que aparecem em textos do passado não sejam mais comuns hoje como, por exemplo, cholerina, termo que significava, segundo Chernoviz (1890, p.585), "molestia que se parece com o primeiro gráo do cholera", mas que não se encontra mais em dicionários contemporâneos, nem mesmo com a letra c em vez do $\mathbf{c h}$-, mas também (ou principalmente) porque - mesmo se tratando de termos que ainda aparecem registrados nos dicionários de hoje ou ainda são usados por indivíduos do presente - o significado social dos termos e das expressões é diferente por serem distintas a época, a sociedade e a cultura. Por exemplo, hoje não se veem pessoas evitando pronunciar a palavra cólera, por pânico ou temor da doença, nem pelo fato de acreditar que aquela palavra seja a própria doença, 
mas essa compreensão do significado da palavra cólera existia socialmente para muitas pessoas, por exemplo, no Ceará oitocentista, como é possível se vislumbrar numa matéria do semanário O Araripe, cujo trecho abaixo demonstra:

O CHOLERA. Como nestes ultimos dias se tem divulgado a noticia de que o cholera morbus, vem pouco e pouco se aproximando de nós, o Araripe julga prestar um valioso serviço aos habitantes desta comarca, e dos lugares que lhe são mais visinhos, indicando-lhes alguns conselhos prudentes confirmados pela experiencia, e desvanecendo esse ou panico, terror imaginario, ${ }^{6}$ que se apodera de todos ao proferir se o nome do cholera; e para desempenhar esta tarefa reservou exclusivamente este numero; cuja leitura recommenda a todos que se interessam pelo bem da humanidade. ${ }^{7}$

Aqui já podemos ver quão estreita, real e concreta pode ser a relação entre a língua e o mundo, pois para muitos indivíduos vale o provérbio nomen est omen, ou seja, um nome é um presságio. No dizer de Porter (1993, p.366):

O mau agouro das palavras reflete o fato banal de que algumas doenças são autenticamente mais dolorosas ou ameaçadoras do que outras. No entanto, muito mais está em jogo. Diferentes termos de doenças transmitem mensagens morais e metafóricas radicalmente distintas.

Como é possível se perceber no trecho da matéria supracitada dO Araripe, em 1856, no Ceará, pânico e terror imaginário já se apoderavam de todos "ao proferir se o nome do cholera".

Dando seguimento a essa proposta de se fazer um estudo de linguística histórica, que inegavelmente tem pontos de contato com várias concepções próprias da sociolinguística, procuraremos enriquecer nossas análises com informações históricas e socioculturais referentes ao Ceará oitocentista para que possamos perscrutar os significados sociais que os termos e expressões em questão tinham no contexto em que foram usados, pois como bem aponta Garrioch (1997, p.121):

O princípio central da sociolinguística é que o falar é um ato cuja importância se situa além da definição literal, contida nos dicionários, das palavras usadas. Nenhum tipo de comunicação, verbal ou nãoverbal, pode ser entendido sem referência ao contexto social no interior do qual é produzido.

\footnotetext{
6 Entendemos ter havido aqui um lapso de impressão. O trecho talvez devesse ser: desvanecendo esse panico ou terror imaginario [sic].

7 O Araripe, n.33, p.1, 16 fev. 1856.
} 
Na novela Violação, entre uma atmosfera pestífera marcante do texto, percebese a presença de um cientificismo no trato linguístico da epidemia de cólera e, no semanário O Araripe, há matérias que ensinam remédios para curar a doença e informações de como se prevenir dela; mas, no tocante ao que nos interessa analisar neste trabalho, sobressaem-se neles alguns termos e expressões com significados sociais que revelam o horror causado pelas epidemias de cólera e de varíola: o flagelo, o caçador, o inimigo de guerra e, por fim, o forasteiro. Analisemolos a seguir.

Em alguns trechos de Violação, a cólera aparece como um flagelo, como um castigo dos céus, do qual o povo deveria se proteger com orações e fé. Termos e expressões tais como "medonha peste", "a invasão do mal" e "o flagelo" (TEÓFILO, 1979, p.236) são recorrentes em várias passagens da novela e revelam que a epidemia de cólera era associada a uma punição advinda de Deus na forma de uma peste.

O parágrafo transcrito a seguir ilustra tal associação:

A população espavorida valeu-se do derradeiro recurso dos abandonados, e todos os dias lá ia em grande romagem à pequena matriz, pedir a Deus que a livrasse da peste. Lembro-me ainda, sentindo um frêmito nos nervos, daquele vozear de náufragos a implorar a misericórdia do céu. Rezavam, em vez de estabelecerem rigorosos cordões sanitários. (TEÓFILO, 1979, p.237).

As atitudes do povo daquela época revelam-nos que essa aproximação da cólera a um flagelo não era só uma metáfora do autor da novela, ela tinha raízes socioculturais, era um significado social corrente entre o povo, pois algumas edições dO Araripe já revelavam esta prática de se procurar a igreja em vez de se porem em prática cuidados sanitários, tais como se lê nesta matéria de 1855:

Agora a nosso Reverendo Parocho corre o dever de chamar o povo a oração, para pedirmos a Deus não nos fulmine com esse terrivel flagello. O que não alcansarmos por meio da oração, nunca obteremos com medidas preventivas: só a infinita bondade de Deos nos pode perservar desses males de que somos dignos; por tanto o Parocho chame o povo a oração, este é o seguro meio de alcançar a graça. ${ }^{8}$

Além disso, notícias desesperadas, tais como esta: "HORROR! O cholera morbus, o anjo do extreminio se aproxima de nós. Grande Deos!", ${ }^{9}$ em que a cólera era comparada a um anjo que vinha para trazer o extermínio de muitas vidas, reforçavam o significado social que esta doença tinha para além dos limites

8 O Araripe, n.20, p.1, 17 nov. 1855.

9 O Araripe, n.10, p.2, 08 set. 1855. 
da língua, ou seja, beirando até mesmo as fronteiras do sobrenatural, como uma coisa contra a qual aquele povo, ignorante em relação a tal moléstia, rogava proteção e piedade divinas, como revela esta manchete de uma notícia sobre várias vítimas da cólera em cidades e vilas da então província de Sergipe: "O cholera se aproxima de nós!!!... / GRANDE DEOS, AMPARAI-NOS COM VOSSA DIVINA MISERICORDIA". ${ }^{10}$

Em outras passagens da novela Violação, a epidemia de cólera aparece metaforizada como uma caçada, sendo a população a presa inocente e indefesa que é inesperadamente e em polvorosa apanhada pela doença, descrita como o caçador certeiro e astucioso, conforme se lê neste parágrafo:

O cólera chegou, mas sem pródromos, sem casos isolados, atacando centenas de pessoas. A confusão foi então horrível, e o pânico tudo avassalou. A população inteira desvairou-se, como um bando de aves bravas que fosse alcançado à noite no quieto pouso pela ofuscação do facho de astuto caçador. (TEÓFILO, 1979, p.237).

Noutra passagem, a população é descrita como carneiros que se veem cercados por lobos (a cólera): "Ao primeiro grito de alarma a população ficou aterrada, como se ela fosse um rebanho de carneiros cercado por uma manada de lobos." (TEÓFILO, 1979, p.248).

Numa matéria do mês de agosto dO Araripe, numa edição do semanário que saiu após uma longa parada (por conta da epidemia que se lançara sobre a população cratense, inclusive sobre os editores do jornal) durante os meses de maio, junho e julho de 1862, ano da chegada fatídica da cólera à cidade do Crato, lemos algo similar a esta metáfora da caçada: "[...] quanto é temerosa a solidão que reina em torno de nós! O monstro cruel devorou centenas de amigos [...] E quantos não terão ainda de sucumbir em luta contra o monstro impenetravel e capcioso?". ${ }^{11}$ Expressões tais como monstro cruel e monstro impenetrável e capcioso revelam esse significado social da cólera como um caçador ou como um assombroso, forte e ardiloso ente devorador de vidas.

Noutros momentos, veem-se, em Violação, os horrores da epidemia assemelhados aos de uma guerra, em que a cólera é o inimigo que a população deveria enfrentar honrosamente até a morte, quase que com espírito patriótico. É o que lemos neste trecho: "E todos nós nos preparávamos, não para resistir ao inimigo, pois não tinha armas a nossa ignorância, mas para morrer." (TEÓFILO, 1979, p.237).

\footnotetext{
10 O Araripe, n.21, p.4, 24 nov. 1855.

11 O Araripe, n.285, p.1, 23 ago. 1862.
} 
Os termos e expressões usados neste trecho a seguir, de uma matéria dO Araripe, demonstram também ser a cólera vista como um inimigo contra quem a população deveria se preparar para guerrear, primeiro se protegendo e criando barreiras, para em seguida morrer gloriosamente sem fugir, pois a deserção era vista como desonra:

Os cordões sanitarios produzem milhores resultados que as quarentenas, bem que não se trate de um contagio e sim de uma epidemia. Algumas pessoas que se tiverem inoculados do mal não transporão a linha, e nosso unico perigo ficará na athmosphera, o q', graças a diversidade do clima, não é muito para assustar.

Quando esta poderosa cautella falhar, resta um não menos efficiente meio de minorar o mal, a coragem. Encaremol-o como um inimigo a cujas mãos pereceremos, si não combatermos até as extremidades. Afrontemol-o, não como Ajax despeitado dos Deoses, porem como o christão na sua resignação evangelica.

A causa de um seja a de todas; maldição ao q' abandonar seo irmão; vergonha ao que fugir. Demos batalha ao inimigo com aquella coragem passiva, q'honra as grandes almas. Quem sobreviver escreva em lettras de ouro a coragem do q' se sacrificar pelo seo semilhante: uma gloria eterna fique ligada a seo nome. ${ }^{12}$

Os termos linha, perigo, coragem, inimigo, combatermos, Ajax, fugir, batalha, sobreviver e glória, presentes neste trecho da matéria supracitada, lembram o campo semântico bélico e reforçam esse significado social da epidemia aproximado da ideia de inimigo de guerra. Mas notemos que, neste caso específico, não se estava evocando uma guerra passional como a de Troia ("Afrontemol-o, não como Ajax despeitado dos Deoses"), mas uma guerra santa como uma cruzada ("porem como o christão na sua resignação evangélica"), em que, da luta pelo semelhante, a recompensa seria memorável e quase celestial ("uma gloria eterna fique ligada a seo nome").

Esta outra matéria dO Araripe trata de forma irônica e desprezível o fato desonroso de um subdelegado ter fugido do Crato na época da epidemia para se refocilar (descansar) na vizinha cidade de Barbalha (provavelmente não tão afetada pela cólera) e voltar forte e vigoroso para prestar de novo seus serviços somente depois dos piores dias:

BOAS NOVAS. - É chegado o impagavel snr. Francisco José de Pontes Simões, o subdelegado deste destricto, que andou refocilando, durante o cholera, pelo termo de Barbalha. A patria agradecida lhe deve remuneração do grande serviço, que prestou á humanidade, favorecendo esta cidade com sua ausencia durante aquelles máos dias. Com effeito

12 O Araripe, n.42, p.1, 26 abr. 1856. 
aguentar o cholera e o snr. Xico, era uma dupla calamidade. A naturesa que lhe pregou errados os dois olhos, cravando-lhe um mais a baixo, outro mais a cima, com vistas para este bordo e bom bordo, quis em compensaçao dotal-o de uma saude de Hercules. Elle veio gordo e rochucxudo [sic] promettendo prestar bons serviços; bem entendido, si não se fallar mais em cholera. Damos pois os nossos emboras ao amavel povo do Crato. ${ }^{13}$

Nessa matéria, pode-se destacar ainda a passagem: "Elle veio gordo e rochucxudo [sic] promettendo prestar bons serviços; bem entendido, si não se fallar mais em cholera.", em que é feita uma alusão - se bem que em tom de chiste - ao temor que o simples falar sobre a cólera sobrevinha a alguns indivíduos.

Entretanto um dos significados sociais mais marcantes, na novela em questão e também fortemente marcada em várias matérias do semanário O Araripe, é a da doença como um forasteiro. Esta é uma das concepções mais evidentes dos aspectos socioculturais do Ceará oitocentista em relação às epidemias. Falando especificamente do Cariri, região ao sul da então província do Ceará, o historiador Figueiredo Filho (2010, p.54) diz:

Desde o seu nascedouro para a vida civilizada, não teve a mais rudimentar assistência médica, até fins do século passado, ${ }^{14}$ a não ser esporadicamente. Vivia então em pleno domínio do curandeirismo, aos métodos primitivos dos pagés [sic] ameríndios, ou mandingueiros de origem africana.

Era, portanto, nesse contexto provinciano e insalubre que se popularizava a ideia das epidemias de cólera e de varíola como algo exótico e invasivo, personificado, sobretudo, na figura lendária do judeu errante, a qual corresponde, com suas raízes na tradição cristã medieval, a uma espécie de resumo dos outros significados sociais identificados: o flagelo, o caçador e o inimigo de guerra.

Já eram conhecidos registros históricos de epidemias de varíola na Grécia, em Roma, no Oriente, na Ásia e na África desde a Antiguidade. Cria-se ter se espalhado a varíola com o estabelecimento de rotas comerciais que passavam pela Índia, onde se cultua, desde épocas remotíssimas, Sitala, a deusa da varíola, invocada para curar doenças contagiosas. Chernoviz (1890, p.325), porém, afirma: “[...] parece que esta calamidade veio da Arabia para outros paizes, em consequencia das conquistas de Mafoma."15

\footnotetext{
13 O Araripe, n.291, p.3, 19 out. 1862.

14 Leia-se século XIX.

15 Antigo antropônimo equivalente a Maomé (570 d.C. - 632 d.C.), mais usado atualmente.
} 
No Brasil, há registros da varíola desde o século XVI, quando matou milhares de indígenas. Apesar de ter sido a doença para a qual primeiro se descobriu uma vacina e de ter sido a primeira doença erradicada pelo homem (em fins do século XVIII, Edward Jenner, um médico britânico, descobriu que a inoculação do vírus vaccinia no homem produzia uma vacina ${ }^{16}$ contra a varíola), no Ceará oitocentista ela ainda era temida, pois causava muitos sofrimentos e mortes.

A cólera, segundo Chernoviz (1890, p.578):

É uma molestia conhecida desde tempo immemorial. [...] A Índia é seu paiz natal. [...] A grande epidemia de cholera que no espaço de alguns annos semeou o terror e a morte em muitos povos da terra, parece ter principiado em Jessora, no Delta do Ganges, em 1817. [...] Foi no anno de 1855 que se declarou pela primeira vez no Rio de Janeiro.

Esta doença bacteriana tinha sua origem histórica associada às abluções dos rituais religiosos dos hindus nas águas do rio Ganges. Naquela época, portanto, acreditava-se que tanto a varíola quanto a cólera tivessem surgido na Índia, se não no Oriente, sendo vistas como terríveis e indesejados invasores estrangeiros.

Um exemplo disso é que em vários trechos de Violação, a cólera é cognominada como algo que vem de fora, exótico, como um bandoleiro que vem causar destruição e morte, como, por exemplo, neste trecho em que aparece a referência ao rio sagrado dos hindus: "Era a primeira vez que o mortífero filho do Ganges nos visitava; que a legião desses infinitamente pequenos deixava a sua terra, para vir empestear a nossa tenda." (TEÓFILO, 1979, p.236).

E numa matéria dO Araripe sobre a varíola, vemos esta doença virótica infectocontagiosa (que na época também era chamada de bexigas, bexiga ou bixiga) sendo comparada ao judeu errante a se aproximar:

A bexiga, este mal terrivel, que tem ceifado preciosas vidas, acaba de devastar grande parte das populações do alto Amasonas, Pará, Maranhão e Pernambuco, e nos ameaça com seos horriveis cortejos; por que sendo esta peste como Judeo errante devemos contar com ella no litoral de nossa província. ${ }^{17}$

Essa mesma concepção de associar uma epidemia à passagem do judeu errante também se encontra noutra matéria dO Araripe sobre a cólera: "O

\footnotetext{
16 O termo vacina, a propósito, vem de vaccinia (nome do vírus que provoca uma espécie de varíola nas vacas) a partir de vacca, ou seja, vaca em latim (CUNHA, 1999).

17 O Araripe, n.1, p.3, 07 jul. 1855.
} 
cholera que tanto tem afligido a raça humana, esse maldito judéo errante ${ }^{18}$ vai-se aproximando de nossa comarca pelo lado de Pajaù de Flores." ${ }^{19}$

A expressão judeu errante poderia, já naquela época, lembrar a figura dos mascates (muitos deles de origem judaica) que andavam por esse Brasil afora, muitas vezes, ludibriando os incautos com a venda de mercadorias sem qualidade e a preços altos. Nos textos pesquisados, porém, esta expressão evoca a lendária personagem do judeu que, por afastar Jesus de sua porta, foi amaldiçoado por Ele, na Via Dolorosa, com a condenação de viver perambulando eternamente até que Ele, Jesus, voltasse.

A figura lendária do judeu errante aparece em muitos relatos desde a Idade Média, muitas vezes associada à ideia do anticristo. Segundo Pires Ferreira (2000, p.4), " [...] a lenda do judeu errante, alegoria e personificação da nação judaica, é anterior ao século XII." e foi usada pela Igreja Católica em discursos antijudaicos ou de conversão ao cristianismo.

Na Europa medieval, o imaginário popular, alimentado pelo discurso católico, associava temporais, ventos fortes, desgraças e pestes à passagem do judeu errante por uma região e, no século XIX, por exemplo, o romance-folhetim Le Juif Errant (O Judeu Errante), de Eugene Sue, publicado na França em 1845, "[...] apresenta o judeu errante como ocasionador de uma epidemia de cólera por onde andasse." (SANTANA JÚNIOR, 2011, p.7).

Não é absurdo, portanto, pensar que tal concepção - de associar a expressão judeu errante à lenda de Ahasverus, ${ }^{20}$ acrescida da crença de que ele levava desgraça por onde passasse -, característica do cristianismo medieval e presente na literatura e no imaginário popular europeu, existisse também no Ceará oitocentista, como sugere aquela prática de rezar para se proteger das doenças.

As populações dos vilarejos e das pequenas cidades do interior, sentindo-se invadidas, em sua paz e tranquilidade, por um desconhecido e indesejado mal estrangeiro a lhes desorganizar a vida, revelavam sua ojeriza a essas doenças exóticas também linguisticamente. O valor social negativo atribuído às doenças era, com fundamento na tradição católica, igualado ao que era atribuído ao judeu errante lendário e que terminava por se estender à nação judaica e ao judaísmo.

18 Tratando exatamente desta passagem, num estudo acerca das representações sobre a cólera no semanário cratense O Araripe, diz Alexandre (2010, p.206): "Nessas condições, a adjetivação judeu errante, utilizada para caracterizar o cólera, é reveladora: a carga de preconceito com que a palavra judeu era tratada pelo catolicismo da época - visto por este como sinônimo dos assassinos de Cristo, dando origem inclusive ao verbo português judiar, no sentido de maltratar - era seguida pela percepção de um vagar sem pouso, já que o povo judeu não tinha um território, um lugar próprio, estando disperso pelo mundo. Desse modo, o epíteto preconceituoso utilizado pelo jornal representava o cólera como um mal que vagava, disseminando a morte ao se espalhar por todos os cantos do globo."

19 O Araripe, n.27, p.4, 5 jan. 1856.

20 Um dos vários nomes dados ao judeu errante lendário. 
As epidemias de varíola e cólera que se abateram sobre o Ceará no século XIX mudaram os hábitos e costumes das populações, trouxeram novas preocupações e medos e alteraram-lhes também a linguagem, proporcionando o surgimento de novos termos, expressões e significados sociais diretamente ligados a elas. Um exemplo disso é uma nota no semanário O Araripe, em que, no ano de 1856, um homem simples (como revelam suas palavras e suas dúvidas) da cidadezinha de Assaré, no interior do Ceará, que se assina por "um sertaneijo", preocupado em aprender a preparar um remédio feito com limão para se prevenir contra a cólera que se anunciava na eminência de aparecer no Cariri cearense, usa em seu texto a expressão maldito cólera ("a humana rassa amiaçada do maldito cholera"21). Essa expressão, aparentemente, foi adquirida a partir do uso que se fazia corriqueiro no contexto sociocultural, histórico e linguístico de então e sugere o significado social de amaldiçoada doença que se anuncia vindoura a nos trazer pavor e morte.

Provavelmente, expressões de uso popular ainda hoje observáveis, sobretudo no Nordeste brasileiro, têm sua origem ligada ao período em que estas e outras doenças faziam estragos terríveis na população local. Assim, quando popularmente se diz, por exemplo, "coceira da bixiga", fala-se de uma coceira sem fim e muito forte; quando se diz: "ele está com a molesta" é o mesmo que dizer "ele está com a bixiga", ou seja, ele está com toda força, ou com raiva, ou com ímpeto. O significado social de tais expressões pode estar associado à intensidade com que se manifestara a moléstia da bexiga (varíola), ainda tão presente na memória histórica e linguística do povo.

\section{Considerações finais}

Estudar um fenômeno linguístico qualquer - como se fez aqui com o significado social de termos e expressões - de um determinado período histórico do passado da língua, carece necessariamente que sejam também considerados os fatores extralinguísticos ou contextuais envolvidos neste fenômeno; caso contrário, muitas questões quedarão sem respostas.

Os registros linguísticos acerca das epidemias de cólera e de varíola, colhidos num jornal e numa obra literária do século XIX no Ceará, que constituíram o corpus deste trabalho, considerados em seus contextos socioculturais e históricos, revelam atitudes tais como a associação das doenças a um castigo dos céus, a um caçador de homens, a um inimigo de guerra e a um intruso forasteiro (o judeu errante).

21 O Araripe, n.30, p.3-4, 26 jan. 1856. 
Os costumes, as práticas, as atitudes místico-religiosas e os temores de um povo que se revelam linguisticamente nos textos analisados não demonstram apenas que a linguagem sirva para representar a realidade, mas - ao ser considerado esse povo fomentando linguisticamente ideais de convívio social, comportamentos, crenças e tabus - demonstram que ela ajuda a moldar a própria realidade de dentro desta mesma realidade, da qual é parte constitutiva.

A relação entre as palavras e as doenças, como aparece nesse contexto específico do Ceará oitocentista, extrapola os limites puramente linguísticos e revela algumas funções da linguagem, pois, nos momentos de aflição, o significado social explode com veemência e sem disfarces, revelando toda a carga de preconceitos e de concepções socialmente construídas. Algumas expressões, tais como judeu errante e anjo do extermínio, eram mais do que sinônimos de cólera e de varíola e possuíam mais que traços de eloquência; elas eram para os homens daquela época como que válvulas de escape de suas aflições e de seus preconceitos socioculturais com requintes de xenofobia, que ecoavam também os tradicionais discursos católicos antijudaicos.

Por onde se manifestavam as epidemias, o espectro da morte rondava os lares e roubava dia a dia crianças, jovens e velhos, parentes, amigos e grande parte da população, principalmente, dos lugares com menos condições de higiene. Então, quando não adiantava mais rezar, nem fugir, nem tomar remédios, restava praguejar, gritar, expressar sua revolta através da linguagem; isso que se pode ver materializado nas passagens analisadas dos textos aqui pesquisados.

Portanto, se quisermos saber como se dava em outras épocas a relação língua-realidade, é preciso escavar os escombros do passado (escombros que, neste trabalho, são as lendas medievais, tradições cristãs, discursos católicos, concepções e preconceitos socioculturais da população, condições de vida no Ceará oitocentista e o despreparo médico-científico de então para enfrentar as epidemias, envolvidos nos significados sociais analisados). E, para isso, nada mais apropriado que perscrutando seus textos e contextos. Por eles o passado dá suas próprias respostas.

\section{Agradecimentos}

Agradecemos aos professores da UFPB Camilo Rosa e Cristina Assis as leituras e observações e também aos professores e bolsistas do Centro de Documentação da URCA a disponibilização dos textos para consultas.

LEITE, F. de F.; ALMEIDA, M. de F. The social meaning of terms and expressions relating to epidemics in the nineteenth century Ceará. Alfa, São Paulo, v.58, n.2, p.441-462, 2014. 
- ABSTRACT: This paper intends to analyze the social meaning of terms and expressions related to epidemics of cholera and smallpox which affected thousands of people in Ceará (Brazil) during the nineteenth century. Our corpus is composed of an 1899 novel called Violação, written by Rodolfo Teófilo; and of some articles from the weekly newspaper known as O Araripe, which was printed from 1855 to 1864 in Crato, Ceará. The main theoretical approach for this research is the Historical Linguistics (lato sensu) studies, associated with the methodology of analysis developed by the Social History of Language, mainly considering the methods used by Burke and Porter $(1993,1997)$ and Burke (2010). In addition to that, our analytical work also comprehends the use of theoretical proposals created by Benveniste (1995, 1989), especially those ones which deal with the relationship between language and reality or between lexicon and culture. The conclusions obtained from our analysis point out that it is necessary to understand the language not as a simulacrum of reality, but as a living part of social, cultural and historical realities of humankind. The relationship between words and diseases can be highlighted by historical and sociocultural conceptions as well as by prejudices; besides that, it also reveals the social functions of the language.

- KEYWORDS: Historical Linguistics. Social history of Language. Violação, by Rodolfo Teófilo. Weekly Araripe. Diseases. Language and reality.

\section{REFERÊNCIAS}

ALEXANDRE, J. F. Quando o "anjo do extermínio" se aproxima de nós: representações sobre o cólera no semanário cratense O Araripe (1855-1864). 2010. 245f. Dissertação (Mestrado em História) - Universidade Federal da Paraíba, João Pessoa, 2010

ALVES, M. D. Desejos de civilização: representações liberais no jornal O Araripe 1855 - 1864. 2010. 148f. Dissertação (Mestrado em História e Culturas) Universidade Estadual do Ceará, Fortaleza, 2010.

AUROUX, S. Filosofia da linguagem. Tradução de Marcos Marcionilo. São Paulo: Parábola, 2009.

BENVENISTE, É. Problemas de linguística geral I. 4.ed. Tradução de Maria da Glória Novale e Maria Luisa Neri. Campinas: Pontes, 1995.

Problemas de linguística geral II. Tradução de Eduardo Guimarães et al. Campinas: Pontes, 1989.

BURKE, P. Linguagens e comunidades nos primórdios da Europa Moderna. Tradução de Cristina Yamagami. São Paulo: Ed. da UNESP, 2010.

O passado é um país estrangeiro. [16 maio 2009]. Entrevista. O Globo, 16 maio 2009. Disponível em: <http://oglobo.globo.com/blogs/prosa/ posts/2009/05/16/peter-burke-passado-um-pais-estrangeiro-186814.asp > . Acesso em: 13 abr. 2012. 
BURKE, P.; PORTER, R. (Org.). História social da linguagem. Tradução de Álvaro Hattnher. São Paulo: Ed. da UNESP, 1997.

. Linguagem, indivíduo e sociedade: história social da linguagem. Tradução de Álvaro Luiz Hattnher. São Paulo: Ed. da UNESP, 1993.

CHERNOVIZ, P. L. N. Diccionario de medicina popular e das sciencias accessorias... 6.ed. consideravelmente aumentada, posta a par da ciência. Paris: A. Roger \& F., 1890. 2 v. Disponível em: <http://www.brasiliana.usp.br/pt-br/dicionario/ edicao/4>. Acesso em: 14 abr. 2012.

COLARES, O. Introdução crítica: fome e peste na ficção de Rodolfo Teófilo. In: TEÓFILO, R. A fome; Violação. Organização, atualização e notas de Otacílio Colares. Rio de Janeiro: J. Olympio; Fortaleza: Academia Cearense de Letras, 1979. p.ix-Xviii.

CUNHA, A. G. da. Dicionário etimológico Nova Fronteira da língua portuguesa. 2.ed. rev. e acrescida de um suplemento. Rio de Janeiro: Nova Fronteira, 1999.

FERREIRA, A. B. de H. Novo Dicionário Aurélio da Língua Portuguesa. 3.ed. $1^{\text {a }}$. impressão da Editora Positivo, rev. e atual. do Aurélio Século XXI. [S.l.]: Positivo Informática, 2012. Disponível em: <http://www.aureliopositivo.com.br/>. Acesso em: 16 abr. 2012.

FIGUEIREDO FILHO, J. de. História do Cariri. Fortaleza: Edições UFC: Secretaria da Cultura do Ceará: Edições URCA, 2010. v.4.

GARRIOCH, D. Insultos verbais na Paris do século XVIII. In: BURKE, P.; PORTER, R. (Org.). História social da linguagem. Tradução de Álvaro Hattnher. São Paulo: Ed. da UNESP, 1997. p.121-140.

HYMES, D. Posfácio. In: BURKE, P.; PORTER, R. (Org.). Linguagem, indivíduo e sociedade: história social da linguagem. Tradução de Álvaro Luiz Hattnher. São Paulo: Ed. da UNESP, 1993. p.431-453.

LEITE, F. de F. O Latim em Cartas do Cariri Cearense: final do século XIX e início do século XX. João Pessoa: Ideia, 2009.

O ARARIPE. Crato: Partido Liberal, 1855-1864. Disponível em: < http:// hemerotecadigital.bn.br/acervo-digital/araripe/213306 >. Acesso em: 14 abr. 2012.

PINTO, L. M. da S. Diccionario da Lingua Brasileira. Ouro Preto: Typographia de Silva, 1832. Disponível em: <http://www.brasiliana.usp.br/dicionario/edicao/3>. Acesso em: 14 abr. 2012.

PIRES FERREIRA, J. O judeu errante: a materialidade da lenda. Revista Olhar, São Carlos, v.1, n.3, p.1-7, jun. 2000. 
PORTER, R. "Expressando sua enfermidade": a linguagem da doença na Inglaterra georgiana. In: BURKE, P.; PORTER, R. (Org.). Linguagem, indivíduo e sociedade: história social da linguagem. Tradução de Álvaro Luiz Hattnher. São Paulo: Ed. da UNESP, 1993. p.365-394.

SANTANA JÚNIOR, F. O. A lenda cristã do mito do judeu errante, sua desconstrução judaica e sua recriação estética na novela de Samuel Rawet. In: SILEL - SEMINÁRIO INTERNACIONAL DE LETRAS E LINGUÍSTICA, 3., 2011, Uberlândia. Anais... Uberlândia: EDUFU, 2011. v.2, p.1-17.

SILVA, A. M. Diccionario da lingua portugueza. Lisboa: Typographia Lacerdina, 1813. Disponível em: <http://www.brasiliana.usp.br/pt-br/dicionario/edicao/2>. Acesso em: 14 abr. 2012.

SILVA, R. V. M. e. Caminhos da linguística histórica: ouvir o inaudível. São Paulo: Parábola, 2008.

TEÓFILO, R. Violação. In: A fome; Violação. Organização, atualização e notas por Otacílio Colares. Rio de Janeiro: J. Olympio; Fortaleza: Academia Cearense de Letras, 1979. p.235-256.

Recebido em novembro de 2012.

Aprovado em maio de 2013. 